\title{
PRIMARY FINDINGS OF THE RESEARCH ON ICT LITERACY EDUCATION PUPILS' AND TEACHERS' ICT COMPETENCIES IN PRIMARY AND LOWER SECONDARY SCHOOLS
}

\section{Abstract}

In 2012 and 2013, the authors of this paper worked on the Czech Science Foundation Project - Information Technology Competencies of Children and Their Development in Primary and Lower Secondary Schools. This article briefly reports on this project focused on examining the current state, structure and trends in development of ICT literacy education in Czech primary (ISCED 1) and lower-secondary schools (ISCED 2). 1,183 schools (ICT teachers) and 2,507 pupils joined the project. It presents the key findings of the research in particular issues including characteristics and thematic units of educational ICT activities, pupils' information technology skills development and implementation of ICT competencies into educational activities. The research follows up on a similarily orientated project realized in 2006, in which the relevant data was obtained from 930 schools and it seeks to update and compare these research findings.

\section{Key Words}

Education, ICT literacy education, ICT skills, teacher's information technology competencies

\section{Vladimír Rambousek, Jiří Štípek, Josef Procházka} Charles university in Prague, Faculty of Education vladimir.rambousek@pedf.cuni.cz

\section{ARTICLE INFO}

Article type

Full research paper

doi: 10.7160/eriesj.2013.060404

Article history

Received: July 31, 2013

Received in revised form: October 5, 2013

Accepted: October 11, 2013

Available on-line: December 30, 2013 


\section{Introduction}

In the context of a rapid development of society, new requirements emerge reflecting newly emphasised clusters of knowledge, skills and attitudes, which people should acquire since they could be practically as significant for the quality of their personal and professional life as basic literacy. Information technology competencies rank among top of newly significant competencies, therefore broadly understood information or ICT literacy became to be seen as the second, or new literacy. ICT literacy education aiming to build up information technology literacy and develop its skills has become the object of the attention of a number of conceptual and programme documents and also lifelong learning aims (e.g. European Commission, 2006; Anderson, 2008; Ala-Mutka, et al, 2008; European Commission, 2010; ITU, 2012).

Indisputably, within formal or initial education, primary and lower-secondary schools play an important role in providing ICT literacy education and developing information technology competencies, or cognitive and operational skills and attitudes necessary for the effective use of information and communication technologies. Modern ICT literacy education comes from the awareness of the key role of ICT literacy education when building up information technology literacy and target development of information technology competencies within initial education. Last but not least, it comes from a strong belief that current understanding of ICT literacy education must support the development of the abilities, or competencies enhancing pupils' adaptability, knowledge and skill transfer into new contexts and the ability to learn in a rapidly changing environment. It is to develop pupils' critical thinking skills, their ability to make a decision and argue reasonably, it is to develop algorithmic thinking and problem-solving skills; it is to enhance creativity and creative thinking in pupils.

These features lead to application of competence approach with the support of transmittance of knowledge and skills in ICT literacy education leading to the development of key competencies building up information technology literacy (Eurydice, 2002; European Parliament and the Council, 2006; Ala-Mutka, 2011).

The implementation of ICT literacy education as obligatory part of primary and lower-secondary school curriculum in the subject and cross-curricular level is a feature of school systems of developed countries. However, ICT literacy education is not realized uniformly and differences among the systems can be seen in organization, extent and forms of educational activities (areas, subjects, thematic units, projects) and their conception. We may consider a wide spectrum of approaches ranging from limiting information, or ICT literacy education to practising mastering software tools for searching and processing primarily text information on the one hand, to the approach emphasizing pupils' algorithmic thinking development on the other hand.

The above-mentioned premises were also used in the research project Research of ICT Literacy Education 2006 (VIV06), which was carried out by the staff of the Faculty of Education at Charles University, Prague; with the support of the Ministry of Education, Youth and Sports, the Czech Republic. The research was focused on a wide area of ICT literacy education within the primary and lower-secondary education in the Czech Republic. The research was based on a large explorative survey whose target group were the teachers of ICT-orientated subjects. 
Relevant data were gathered from 930 respondents representing individual primary and lower-secondary schools (Rambousek et al, 2007).

In 2012, a two-year long research project Czech Science Foundation Information Technology Competencies of Children and their Development in Primary and Lower Secondary Schools (VIV12) was initiated whereby the staff of the Faculty of Education at Charles University, Prague, intend to follow up the project VIV06 and carry out a similarly large survey in Czech primary (ISCED 1) and lower-secondary (ISCED 2) schools.

The main aim of the VIV12 project is to understand the current state, structure, orientation and tendencies from the point of view of information-technological, or ICT skills of pupils in respect to building up a certain level of their information technology literacy. The applied goal of the project was to acquire relevant groundwork for the improvement of ICT literacy education in primary and lower-secondary schools, as well as the improvement of relevant teachers' education and preparation.

The object of research activity within the VIV12 project is the development of pupils' information technology competencies and its main determinants. Such a generally defined research topic can be rendered specific in five problem areas: First we focused on educational activities developing pupils' information technology, or ICT skills at primary school. Various types of activities were considered and the main attention was paid to compulsory ICT subjects. Then we focused on the content of educational ICT activities. We considered a wide spectrum of topics, or thematic units comprising possible content of educational ICT activities. The third area concerned the current state and development of pupils' information technology, or ICT competencies at primary school. Competencies of various levels of generality understood as parts of pupils' information technology literacy were considered. The fourth area comprised a set of teachers' competencies. ICT competencies of teachers of educational ICT activities were primarily considered. The fifth area concerned the implementation of ICT competencies into pupils' and teachers' educational activities. We explored indicators of introducing ICT into pupil's standard learning activities and teacher's standard teaching activities and into school learning environment understood as an opportunity to use and develop pupils' and teachers' information technology competencies.

\section{Material and Methods}

As a basic tool for first stage of researching the aspects of ICT literacy education, an elaborated questionnaire with 17 complex questions including 186 partial questions was developed by the research team.

The questionnaire was designed for teachers of ICT subjects (a questionnaire for teachers). Following the above mentioned research areas the questionnaire was divided into the following thematic parts: a) Characteristics of educational ICT activities, b) Thematic units of educational ICT activities, c) Current state of pupils' information technology competencies development, d) Structure of teachers' ICT competencies, e) Implementation of ICT competencies into educational activities.

The questionnaire was designed in the way that supported a manipulation with graphic elements (matching, regrouping, replacing) on the computer screen, enabling the ability to record and evaluate the respondents' activity. This solution was chosen on the presumption that using graphic objects, i.e. symbols or headings as objects, allow the respondents to react 
more directly, often even faster, with the possibility of using the layout of the elements and intuitive solution, without need to code, or decode the answers. (Štípek et al, 2008).

Within the first stage of the research VIV12, the said questionnaire was employed with 3,500 randomly selected schools in February and March 2013. At this stage, research data were obtained from 1,183 respondents representing different primary schools (usually one respondent from each school). Due to the fact that each school was represented by one respondent, the response rate was $34 \%$.

The gathered data were subject to statistical analyses including basic descriptive statistics, cluster analyses and exploration of the subgroup properties. In order to compare the gathered data sets and evaluate the statistical significance of differences between the VIV06 and VIV12 research samples, the nonparametric Mann-Whitney rank U-test was employed. To reject the null hypothesis of no difference between the samples a critical significance level of $\alpha=0.01$ was used.

The questionnaire survey undertaken in the first stage of the project (a questionnaire for teachers) is supplemented with other research methods in the second stage of the project. 146 schools participated in the second stage of the project aimed at schools interested in closer cooperation. They administered a questionnaire for pupils, which was completed by 2,507 pupils from 112 schools. A questionnaire for pupils consisted of 12 complex questions and 143 partial questions and was similar to the questionnaire for teachers in order to encourage the use of graphic items.

In addition to the questionnaire for pupils, another survey was carried out for those who were interested, in which 84 teachers expressed their opinions and experience concerning ICT literacy education and primary school pupils' information technology competencies development, for which there was not enough room in the questionnaire for teachers.

The last empirical method was a method of case studies of the implementation of ICT competencies into pupils' and teachers' educational activities.

\section{Results}

The following part presents selected primary findings obtained within the research areas of the first stage of the VIV12 research project. We will also show selected comparisons with the VIV06 project (Rambousek et al., 2008; Procházka et al., 2010).

\section{a) Characteristics of educational ICT activities}

Educational ICT activities are realized in primary and lowersecondary schools in a more extended spectrum through obligatory and optional subjects focused on ICT, integrating informatics or ICT topics into other subjects, using ICT in other subjects and realizing informatics-orientated projects, as Table 1 shows.

\begin{tabular}{|l|c|c|c|c|}
\cline { 2 - 5 } \multicolumn{1}{c|}{} & \multicolumn{2}{c|}{ ISCED 1 } & \multicolumn{2}{c|}{ ISCED 2 } \\
\hline Educational ICT activities & n-abs & n-rel & n-abs & n-rel \\
\hline Compulsory ICT-orientated subjects & 846 & $90.5 \%$ & 893 & $97.3 \%$ \\
\hline ICT specific topics in other subjects & 242 & $25.9 \%$ & 412 & $44.9 \%$ \\
\hline ICT-orientated projects & 135 & $14.4 \%$ & 326 & $35.5 \%$ \\
\hline Using ICT in various subjects & 701 & $75.0 \%$ & 771 & $84.0 \%$ \\
\hline $\begin{array}{l}\text { Non-compulsory ICT-orientated } \\
\text { subjects or clubs }\end{array}$ & 318 & $34.0 \%$ & 370 & $40.3 \%$ \\
\hline
\end{tabular}

Table 1: Absolute (n-abs) and relative (n-rel) frequency distribution of the respondents' choices in terms of educational ICT activities 
Educational ITC activities are mostly (90.5\%) performed within a compulsory subject in primary schools (ISCED 1). We can also quite often find ICT in non-ICT subjects (75\%). In lowersecondary schools (ISCED 2), a compulsory ICT subject is virtually present in all cases (97\%). Other types of activities also show a noticeable rise. Using ICT in the subjects, which are not primarily oriented on ICT or informatics, accounts for the majority of all educational ICT activities in primary and lower-secondary schools. This is a positive shift in contrast to the findings of the project VIV06.

The provision of a compulsory ICT subject proves that a compulsory subject is usually introduced as late as in the 5th grade of primary school. It has a provision of 1 lesson per week. In lower-secondary school, the compulsory subject has the highest provision in the 6th grade and then it gradually decreases. Unlike in primary school, it has a significant provision of 2 lessons a week in all grades (refer to Table 2).

\begin{tabular}{|c|c|c|c|c|c|c|c|c|c|}
\cline { 2 - 9 } \multicolumn{1}{c|}{} & $1 . \mathrm{g}$ & $2 . \mathrm{g}$ & $3 . \mathrm{g}$ & $4 . \mathrm{g}$ & $5 . \mathrm{g}$ & $6 . \mathrm{g}$ & $7 . \mathrm{g}$ & $8 . \mathrm{g}$ & $9 . \mathrm{g}$ \\
\hline$\underset{\mathrm{z}}{\mathrm{z}}$ & $3.2 \%$ & $5.3 \%$ & $13.5 \%$ & $34.9 \%$ & $89.8 \%$ & $76.1 \%$ & $60.8 \%$ & $52.6 \%$ & $49.6 \%$ \\
\hline$\underset{\mathrm{z}}{\mathrm{z}}$ & $0.4 \%$ & $0.2 \%$ & $0.4 \%$ & $1.4 \%$ & $3.4 \%$ & $13.1 \%$ & $12.7 \%$ & $12.8 \%$ & $14.1 \%$ \\
\hline$\underset{\mathrm{z}}{\mathrm{z}}$ & $0.1 \%$ & $0.4 \%$ & $0.4 \%$ & $0.6 \%$ & $0.4 \%$ & $0.3 \%$ & $1.1 \%$ & $1.9 \%$ & $2.4 \%$ \\
\hline
\end{tabular}

Table 2: Relative frequency distribution of the respondents' choices in terms of a set amount of compulsory ICT lessons per week $(\mathrm{g}=$ grade, lpw = lesson per week)

\section{b) Thematic units of educational ICT activities}

Regarding the significance of thematic units of ICT-orientated subjects for developing information technology literacy of the primary and lower-secondary school pupils, the respondents consider the following for the key thematic units. Searching for and retrieving information from the internet, Word processing and Safety on the internet, copyright, ethical principles. In contrast to the findings of the VIV06 project, Creating and using presentations, ranked among the most significant thematic units (refer to Table 3).

Among the least significant thematic units of ICT-orientated subjects with the viewpoint of developing primary and lowersecondary school pupils' information technology literacy belong the following (ranked from the least preferred): Algorithm design and programming, Using databases, Creating and publishing websites. Even though we cannot agree with ranking the above mentioned thematic units among the less significant from a standpoint of current understanding of ICT literacy education, this evaluation is the same as in the VIV06 project.

\begin{tabular}{|l|c|c|}
\cline { 2 - 3 } \multicolumn{1}{l|}{} & $\mathrm{A}$ & $\mathrm{M}$ \\
\hline $\begin{array}{l}\text { Searching for and retrieving information from the } \\
\text { internet }\end{array}$ & 85.6 & 93 \\
\hline $\begin{array}{l}\text { Word processing - editing documents, basics of } \\
\text { typography }\end{array}$ & 84.7 & 90 \\
\hline Safety on the internet, copyright, ethical principles & 83.4 & 94 \\
\hline $\begin{array}{l}\text { Creating and using presentations - working with } \\
\text { presentation applications }\end{array}$ & 74.2 & 77 \\
\hline $\begin{array}{l}\text { Basic user skills, working in an operating system, file } \\
\text { management }\end{array}$ & 73.3 & 81 \\
\hline Communication and cooperation in digital environment & 70.1 & 74 \\
\hline
\end{tabular}




\begin{tabular}{|l|c|c|}
\cline { 2 - 3 } \multicolumn{1}{l|}{} & $\mathrm{A}$ & $\mathrm{M}$ \\
\hline $\begin{array}{l}\text { Working with spreadsheets - processing data, creating } \\
\text { tables and graphs }\end{array}$ & 66.0 & 73 \\
\hline Computer graphics - editing and creating graphics & 61.6 & 64 \\
\hline $\begin{array}{l}\text { PC hardware and software - the structure and functions } \\
\text { of computers }\end{array}$ & 57.8 & 52 \\
\hline $\begin{array}{l}\text { Audio and video on the computer - using and } \\
\text { producing multimedia }\end{array}$ & 48.6 & 50 \\
\hline $\begin{array}{l}\text { Basics of information theory (e.g. types, size, sources, } \\
\text { storing, transfer) }\end{array}$ & 46.0 & 49 \\
\hline $\begin{array}{l}\text { Creating and publishing websites (HTML, CSS, PHP } \\
\text { etc.) }\end{array}$ & 35.0 & 29 \\
\hline $\begin{array}{l}\text { Using databases - fundamentals of database systems, } \\
\text { database design }\end{array}$ & 25.9 & 22 \\
\hline $\begin{array}{l}\text { Algorithm design and programming - developing } \\
\text { algorithmic thinking }\end{array}$ & 25.7 & 20 \\
\hline
\end{tabular}

Table 3: Evaluation of the importance of thematic units of educational ICT activities for pupils' ICT literacy development - ranked from the highest average score on 0 - 100 scale ( $\mathrm{A}=$ arithmetic mean, $\mathrm{M}=$ median)

From the viewpoint of investigating real preferences for thematic units of ICT subjects, we created a hypothetical situation where the amount of lessons was significantly decreased and so the content of ICT subject was also noticeably reduced. Respondents could choose from 5 thematic units, which they would keep, but at the same time 5 units that they would give up. Complete relative frequencies are presented in the Figure 1:

The real preferences for thematic units of ICT subjects were not changed in comparation with findings of the project VIV06. In this connection, we may also conclude that the structure of teachers' information technology skills significantly influences the choice of key and inessential units. Respondents mention very often as key units those which they can master themselves easily, and on the contrary, as the unnecessary ones those for which their information technology skills are on a lower level.

\begin{tabular}{|l|c|r|}
\cline { 2 - 3 } \multicolumn{1}{l|}{} & keep & give up \\
\hline $\begin{array}{l}\text { Word processing - creating } \\
\text { and editing documents }\end{array}$ & $86.3 \%$ & $1.1 \%$ \\
\hline $\begin{array}{l}\text { Searching for and retrieving } \\
\text { information from the internet }\end{array}$ & $79.1 \%$ & $1.7 \%$ \\
\hline $\begin{array}{l}\text { Safety on the internet, } \\
\text { copyright, ethical principles }\end{array}$ & $58.8 \%$ & $1.4 \%$ \\
\hline $\begin{array}{l}\text { Creating and using } \\
\text { presentations }\end{array}$ & $45.7 \%$ & $6.0 \%$ \\
\hline $\begin{array}{l}\text { Basic user skills, working in an } \\
\text { operating system }\end{array}$ & $45.1 \%$ & $16.3 \%$ \\
\hline $\begin{array}{l}\text { Working with spreadsheets - } \\
\text { processing data, creating tables }\end{array}$ & $41.6 \%$ & $17.5 \%$ \\
\hline $\begin{array}{l}\text { Communication/cooperation in } \\
\text { digital environment }\end{array}$ & $37.3 \%$ & $23.8 \%$ \\
\hline $\begin{array}{l}\text { PC HW and SW - the structure } \\
\text { and functions of computers }\end{array}$ & $29.5 \%$ & $33.2 \%$ \\
\hline $\begin{array}{l}\text { Computer graphics - editing } \\
\text { and creating graphics }\end{array}$ & $28.3 \%$ & $27.9 \%$ \\
\hline $\begin{array}{l}\text { Audio and video on the PC-- } \\
\text { using/producing multimedia }\end{array}$ & $5.3 \%$ & $58.0 \%$ \\
\hline $\begin{array}{l}\text { Basics of information theory } \\
\text { (e.g. types, size, sources) }\end{array}$ & $4.6 \%$ & $62.3 \%$ \\
\hline $\begin{array}{l}\text { Algorithm design and } \\
\text { programming }\end{array}$ & $2.4 \%$ & $51.9 \%$ \\
\hline $\begin{array}{l}\text { Creating and publishing } \\
\text { websites (HTML, CSS, PHP) }\end{array}$ & $1.5 \%$ & $73.4 \%$ \\
\hline $\begin{array}{l}\text { Using databases - } \\
\text { fundamentals of DB systems }\end{array}$ & $0.2 \%$ & $80.9 \%$ \\
\hline
\end{tabular}

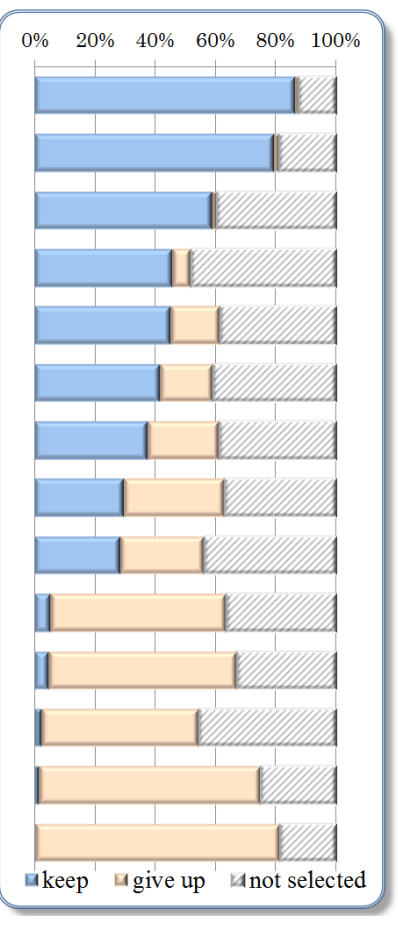

Figure 1: Respondents' choices distribution from the viewpoint of keeping or giving up thematic units of ICT subjects - ranked from the thematic unit with the most frequent preference - the remaining percentage matches the number of respondents with no opinion 
As for the relation between the thematic units and pupils' age, we investigated teachers' opinions on the most suitable period for introducing the thematic unit, whether it should be in primary school, lower-secondary school or as late as in upper-secondary school. A number of topics showed, however, ambiguous results (refer to Table 4).

According to most respondents, the following thematic units should be definitely introduced in primary school: Safety on the internet, copyright, ethical principles, Searching for and retrieving information from the internet, Word processing and Basic user skills. In lower-secondary school, mainly thematic units such as Working with spreadsheets, Audio and video on the computer and Creating and using presentations should be introduced. Most respondents shift the introduction of the following thematic units only to upper-secondary school: Using databases, Algorithm design and programming, Creating and publishing websites. If we take the value "I don't know" for a degree of expressing uncertainty, or difficulty making a decision, then Algorithm design and programming shows the highest degree of uncertainty.

\begin{tabular}{|l|c|c|c|}
\cline { 2 - 4 } \multicolumn{1}{l|}{} & PS & LSS & USS \\
\hline $\begin{array}{l}\text { Safety on the internet, copyright, ethical } \\
\text { principles }\end{array}$ & $0.89 \%$ & $10.20 \%$ & $0.50 \%$ \\
\hline $\begin{array}{l}\text { Searching for and retrieving information } \\
\text { from the internet }\end{array}$ & $0.85 \%$ & $15.20 \%$ & $0.30 \%$ \\
\hline $\begin{array}{l}\text { Word processing - creating and editing } \\
\text { documents }\end{array}$ & $0.83 \%$ & $17.00 \%$ & $0.30 \%$ \\
\hline $\begin{array}{l}\text { Basic user skills, working in an operating } \\
\text { system }\end{array}$ & $0.59 \%$ & $32.90 \%$ & $6.60 \%$ \\
\hline $\begin{array}{l}\text { Communication and cooperation in } \\
\text { digital environment }\end{array}$ & $0.49 \%$ & $47.10 \%$ & $3.50 \%$ \\
\hline
\end{tabular}

\begin{tabular}{|l|l|l|l|}
\hline $\begin{array}{l}\text { PC HW and SW - the structure and } \\
\text { functions of computers }\end{array}$ & $0.44 \%$ & $52.20 \%$ & $3.30 \%$ \\
\hline $\begin{array}{l}\text { Computer graphics - editing and creating } \\
\text { graphics }\end{array}$ & $0.36 \%$ & $55.40 \%$ & $8.40 \%$ \\
\hline $\begin{array}{l}\text { Creating and using presentations - } \\
\text { working with presentation }\end{array}$ & $0.26 \%$ & $71.30 \%$ & $2.00 \%$ \\
\hline $\begin{array}{l}\text { Basics of information theory (e.g. types, } \\
\text { size, sources) }\end{array}$ & $0.14 \%$ & $61.80 \%$ & $21.80 \%$ \\
\hline $\begin{array}{l}\text { Working with spreadsheets - processing } \\
\text { data, creating tables }\end{array}$ & $0.12 \%$ & $84.10 \%$ & $3.50 \%$ \\
\hline $\begin{array}{l}\text { Audio and video on the PC - using/ } \\
\text { producing multimedia }\end{array}$ & $0.07 \%$ & $72.40 \%$ & $19.40 \%$ \\
\hline Algorithm design and programming & $0.07 \%$ & $30.10 \%$ & $54.50 \%$ \\
\hline $\begin{array}{l}\text { Creating and publishing websites } \\
\text { (HTML, CSS, PHP etc.) }\end{array}$ & $0.01 \%$ & $42.60 \%$ & $53.50 \%$ \\
\hline $\begin{array}{l}\text { Using databases - fundamentals of } \\
\text { database systems }\end{array}$ & $0.01 \%$ & $22.90 \%$ & $67.50 \%$ \\
\hline
\end{tabular}

Table 4: Respondents' choices distribution from the viewpoint of the most suitable period for introducing the thematic unit ranked from the thematic unit with the most frequent preference (PS = primary school, LSS = lower-secondary school, USS = uppersecondary school) 


\begin{tabular}{|l|c|c|c|}
\cline { 2 - 4 } \multicolumn{1}{l|}{} & $\mathrm{M}$ & $\mathrm{A}$ & $\mathrm{P}$ \\
\hline $\begin{array}{l}\text { PC HW and SW - the structure and functions of } \\
\text { computers }\end{array}$ & 2 & 2.68 & 14.64 \\
\hline Basic user skills, working in an operating system & 2 & 3.13 & 18.95 \\
\hline Safety on the internet, copyright, ethical principles & 3 & 3.15 & 19.81 \\
\hline $\begin{array}{l}\text { Word processing -editing documents, basics of } \\
\text { typography }\end{array}$ & 4 & 4.02 & 26.76 \\
\hline $\begin{array}{l}\text { Searching for and retrieving information from the } \\
\text { internet }\end{array}$ & 4 & 4.43 & 31.15 \\
\hline $\begin{array}{l}\text { Communication and cooperation in digital } \\
\text { environment }\end{array}$ & 6 & 6.23 & 45.62 \\
\hline $\begin{array}{l}\text { Computer graphics - editing and creating graphics } \\
\text { Basics of information theory (e.g. types, size, }\end{array}$ & 6 & 6.00 & 44.39 \\
\hline $\begin{array}{l}\text { sources, storing) } \\
\text { Working with spreadsheets - processing data, } \\
\text { creating tables }\end{array}$ & 7 & 7.83 & 40.96 \\
\hline $\begin{array}{l}\text { Creating and using presentations - presentation } \\
\text { applications }\end{array}$ & 7 & 7.08 & 54.92 \\
\hline $\begin{array}{l}\text { Audio and video on the computer - using/ } \\
\text { producing multimedia }\end{array}$ & 10 & 9.28 & 71.98 \\
\hline Algorithm design and programming & 11 & 9.50 & 74.67 \\
\hline $\begin{array}{l}\text { Creating and publishing websites (HTML, CSS, } \\
\text { PHP etc.) }\end{array}$ & 11 & 10.28 & 81.87 \\
\hline $\begin{array}{l}\text { Using databases - fundamentals of database } \\
\text { systems/design }\end{array}$ & 12 & 10.67 & 85.27 \\
\hline
\end{tabular}

Table 5: Thematic units in terms of their order of teaching - ranked from the earliest taught thematic units - in the case of equal medians, the order is determined by mean

$(\mathrm{M}=$ median, $\mathrm{A}=$ arithmetic mean. $\mathrm{P}=$ position - evaluated on $0-100$ scale)
From the viewpoint of continuity, or the order of teaching thematic units of ICT subjects, respondents responded by placing particular symbols on the timeline. Within a basic analysis, each thematic unit was given median ranking representing an overall view of the order of thematic units as they are usually taught at school. At the same time, starting and closing thematic units were placed on the timeline as Table 5 shows.

The greatest differences in respondents' opinions on the sequence of thematic units, or on the order in which they should be taught, concerned the following thematic units: Basics of information theory, Computer graphics, Communication and cooperation in digital environment.

Algorithm design and programming are ranked among the introductory topics mainly by beginning teachers. Respondents with longer teaching careers prefer to rank this unit into later teaching, best into secondary school teaching. These findings are virtually the same as the findings of the VIV06 project.

The provision of thematic units was investigated only in a bipolar way. Respondents arranged units into two groups. This way they expressed their opinion on which unit they spend the most time and on which unit they spend the least time (refer to Table 6). 


\begin{tabular}{|l|c|c|c|}
\cline { 2 - 4 } \multicolumn{1}{l|}{} & most & least & $\begin{array}{c}\text { not } \\
\text { sel. }\end{array}$ \\
\hline $\begin{array}{l}\text { Word processing - creating and editing } \\
\text { documents }\end{array}$ & $87.9 \%$ & $0.9 \%$ & $11.2 \%$ \\
\hline $\begin{array}{l}\text { Searching for and retrieving information } \\
\text { from the internet }\end{array}$ & $64.6 \%$ & $7.4 \%$ & $28.0 \%$ \\
\hline $\begin{array}{l}\text { Safety on the internet, copyright, ethical } \\
\text { principles }\end{array}$ & $55.4 \%$ & $18.0 \%$ & $26.6 \%$ \\
\hline Creating and using presentations & $55.4 \%$ & $10.7 \%$ & $33.9 \%$ \\
\hline $\begin{array}{l}\text { Working with spreadsheets - processing } \\
\text { data, creating tables }\end{array}$ & $48.4 \%$ & $15.2 \%$ & $36.4 \%$ \\
\hline $\begin{array}{l}\text { Computer graphics - editing and creating } \\
\text { graphics }\end{array}$ & $42.3 \%$ & $15.7 \%$ & $42.0 \%$ \\
\hline $\begin{array}{l}\text { Basic user skills, working in an operating } \\
\text { system }\end{array}$ & $37.2 \%$ & $20.4 \%$ & $42.4 \%$ \\
\hline $\begin{array}{l}\text { Communication and cooperation in } \\
\text { digital environment }\end{array}$ & $25.7 \%$ & $26.5 \%$ & $47.8 \%$ \\
\hline $\begin{array}{l}\text { PC HW and SW - the structure and } \\
\text { functions of computers }\end{array}$ & $23.5 \%$ & $44.5 \%$ & $32.0 \%$ \\
\hline $\begin{array}{l}\text { Basics of information theory (e.g. types, } \\
\text { size, sources) }\end{array}$ & $10.2 \%$ & $35.8 \%$ & $53.9 \%$ \\
\hline $\begin{array}{l}\text { Audio and video on the PC - using/ } \\
\text { producing multimedia }\end{array}$ & $9.0 \%$ & $31.2 \%$ & $59.8 \%$ \\
\hline $\begin{array}{l}\text { Creating and publishing websites } \\
\text { (HTML, CSS, PHP etc.) }\end{array}$ & $6.7 \%$ & $31.4 \%$ & $61.9 \%$ \\
\hline Algorithm design and programming & $2.9 \%$ & $33.9 \%$ & $63.2 \%$ \\
\hline $\begin{array}{l}\text { Using databases - fundamentals of } \\
\text { database systems/design }\end{array}$ & $0.9 \%$ & $32.0 \%$ & $67.1 \%$ \\
\hline
\end{tabular}

Respondents spend the most time on the following thematic units: Word processing, Searching for and retrieving information from the internet, Safety on the internet, copyright, ethical principles and Creating and using presentations.

Respondents spend the least time on the following thematic units: PC hardware and software, Basics of information theory and Algorithm design and programming.

To get a clearer picture of a thematic focus of ICT education, respondents were given non-traditional units and approaches to teaching, which are typically considered extending and extra-curricular, or relatively new, or promising in connection with ICT development (refer to Table 7).

From these thematic units, respondents most often use the following: Using cloud applications, Programmable robot kits and Mind mapping and concept mapping. They most often consider using thematic unit Introductory programming languages. They least often use thematic units Social networks and Basics of computer networks.

Table 6: Provision of thematic units of ICT subjects (not sel. $=$ not selected) 


\begin{tabular}{|l|c|c|c|}
\cline { 2 - 4 } \multicolumn{1}{c|}{} & We use & \begin{tabular}{c} 
We \\
consider \\
\hline Using cloud applications
\end{tabular} & $\begin{array}{c}\text { Not } \\
\text { selected }\end{array}$ \\
\hline Programmable robot kits & $36.9 \%$ & $12.0 \%$ & $51.1 \%$ \\
\hline Mind mapping and concept mapping & $25.8 \%$ & $10.2 \%$ & $62.0 \%$ \\
\hline Touch typing & $23.0 \%$ & $20.1 \%$ & $54.2 \%$ \\
\hline Computer games & $19.7 \%$ & $19.2 \%$ & $57.7 \%$ \\
\hline Introductory programming languages & $17.3 \%$ & $34.9 \%$ & $47.8 \%$ \\
\hline Using portable ICT in education & $13.5 \%$ & $18.2 \%$ & $68.3 \%$ \\
\hline Social networks & $13.0 \%$ & $2.2 \%$ & $84.8 \%$ \\
\hline $\begin{array}{l}\text { Data and information exchange and } \\
\text { sharing }\end{array}$ & $9.2 \%$ & $15.9 \%$ & $74.8 \%$ \\
\hline Basics of computer networks & $3.8 \%$ & $15.6 \%$ & $80.6 \%$ \\
\hline
\end{tabular}

Table 7: Respondents' choices distribution from the viewpoint of implementation extending thematic units - ranked from the thematic unit with the most frequent preference

\section{c) Pupils' ICT competencies development}

In order to evaluate the development of pupils' ICT competencies, we first explored the importance respondents attach to particular competencies for primary and lower-secondary school pupils' ICT literacy development. Competencies of both a higher degree of generality and a lower degree of generality were evaluated by means of two lists. Respondents expressed their opinion on 0-100 scale, for each item separately (refer to Table 8).

\begin{tabular}{|l|c|}
\cline { 2 - 2 } \multicolumn{1}{c|}{} & $\mathrm{A}$ \\
\hline Search for and obtain information & 90.0 \\
\hline Respects of the code of conduct in digital environment & 84.7 \\
\hline $\begin{array}{l}\text { Evaluate and analyse obtained information and distinguish } \\
\text { important information }\end{array}$ & 81.6 \\
\hline Process and integrate information & 78.4 \\
\hline $\begin{array}{l}\text { Present information and store it for the given purpose and } \\
\text { recipients }\end{array}$ & 76.9 \\
\hline Communicate and cooperate in digital environment & 76.4 \\
\hline Know how to use digital technologies & 75.9 \\
\hline Think creatively, create your own products & 74.8 \\
\hline Think critically, make a decision and argue reasonably & 71.0 \\
\hline $\begin{array}{l}\text { Generate new information through interpreting or use } \\
\text { current information }\end{array}$ & 66.7 \\
\hline $\begin{array}{l}\text { Know how to use problem-solving strategies and } \\
\text { information orientated tasks }\end{array}$ & 59.4 \\
\hline Think algorithmically, formulate instructions & 53.3 \\
\hline Understand technological principles and processes & 47.3 \\
\hline
\end{tabular}

Table 8: Importance of ICT competencies of a higher degree of generality - ranked from the competency of the greatest importance

$$
\text { ( } A \text { = arithmetic mean) }
$$

Among the most significant skills from a standpoint of building up and developing primary and lower-secondary school pupils' information technology literacy belong: Search for and obtain information, Respects of the code of conduct in digital environment, Evaluate and analyse obtained information and distinguish important information.

The following aspects are regarded as the most important skills from the skills of lower level of generality linked to concrete activities or applications (refer to Table 9).: Create, edit and 
process documents in a word processor, Use various information sources for information verification, Navigate through various forms of information.

\begin{tabular}{|l|c|}
\cline { 2 - 2 } \multicolumn{1}{l|}{} & $\mathrm{A}$ \\
\hline Create, edit and process documents in a word processor & 85.4 \\
\hline $\begin{array}{l}\text { Use various information sources for information } \\
\text { verification }\end{array}$ & 81.2 \\
\hline $\begin{array}{l}\text { Navigate through various forms of information (graph, } \\
\text { table, scheme, document...) }\end{array}$ & 79.9 \\
\hline $\begin{array}{l}\text { Judge reliability and credibility of electronic information } \\
\text { sources }\end{array}$ & 78.3 \\
\hline Navigate through file tree structure (folders) & 71.6 \\
\hline Understand social, ethical and cultural impacts of ICT use & 71.0 \\
\hline $\begin{array}{l}\text { Create tables and graphs in spreadsheet and make use of } \\
\text { them }\end{array}$ & 65.9 \\
\hline Complete and create and use mind and concept maps & 51.4 \\
\hline $\begin{array}{l}\text { Create www pages in HTML, PHP, JavaScript etc. } \\
\text { languages }\end{array}$ & 31.4 \\
\hline Master the basics of algorithm design and programming & 30.3 \\
\hline
\end{tabular}

Table 9: Importance of ICT competencies of a lower degree of generality - ranked from the competency of the greatest importance

\section{( $\mathrm{A}=$ arithmetic mean)}

From a standpoint of the findings of the VIV06 project, we can note a significant increase of the importance of the skill concerning Judge reliability and credibility of electronic information sources and a soft decrease of the importance of the skill concerning making and editing new documents in the text editor (overall with the average 85 out of 100).
The least important competencies are considered from the skills of a higher degree of generality Think algorithmically, formulate instructions and Understand technological principles and processes.

The following aspects are regarded as the least important skills from the skills of lower level of generality linked to concrete activities or applications from a viewpoint of building up and developing information technology literacy of the primary and lower-secondary school pupils (ranked from the least preferred): Master the basics of algorithm design and programming and Create www pages in HTML, PHP, JavaScript etc. languages. No shift in evaluation was noted compared to the findings of the VIV06 project.

Understanding the importance of information technology competencies and how demanding it is to acquire them correspond to the respondents' attitude to similarly orientated thematic units of ICT-orientated subjects. Skills relating to the thematic units, which are considered as cardinal by the respondents, are perceived as very important for the development of information technology literacy in primary and lower-secondary school and at the same time less demanding for pupils.

The skills, which are considered demanding, are at the same time marked as little important for the development of information literacy in primary and lower-secondary school. On the contrary, the skills considered as undemanding are marked as important part of ICT literacy education in primary and lower-secondary school. 


\begin{tabular}{|l|c|c|}
\hline $\begin{array}{l}\text { We encourage the development of the following pupil's } \\
\text { ability }\end{array}$ & M & A \\
\hline Search for and obtain information & 5 & 4.6 \\
\hline Respects of the code of conduct in digital environment & 4 & 4.1 \\
\hline Process and integrate information & 4 & 4.0 \\
\hline $\begin{array}{l}\text { Present information and store it for the given purpose } \\
\text { and recipients }\end{array}$ & 4 & 3.8 \\
\hline $\begin{array}{l}\text { Evaluate and analyse obtained information and } \\
\text { distinguish important }\end{array}$ & 4 & 3.7 \\
\hline Know how to use digital technologies & 4 & 3.7 \\
\hline Communicate and cooperate in digital environment & 4 & 3.6 \\
\hline Think creatively, create your own products & 4 & 3.6 \\
\hline $\begin{array}{l}\text { Generate new information through interpreting or use } \\
\text { current information }\end{array}$ & 3 & 3.3 \\
\hline Think critically, make a decision and argue reasonably & 3 & 3.2 \\
\hline $\begin{array}{l}\text { Know how to use problem-solving strategies and } \\
\text { information orientated tasks }\end{array}$ & 3 & 2.9 \\
\hline Understand technological principles and processes & 3 & 2.7 \\
\hline Think algorithmically, formulate instructions & 2 & 2.5 \\
\hline
\end{tabular}

Table 10: Evaluation of the degree of agreement of particular statements - ranked from the highest resulting agreement of the statement - in the case of equal medians, the order is determined by mean $(\mathrm{M}=$ median, $\mathrm{A}=$ arithmetic mean $)$

From the viewpoint of the environment for pupils' ICT competencies development, respondents expressed their opinion on various statements and they compared their degree of agreement with the current situation of their school. They evaluated each statement on a 5-point scale (no, very little, partially, rather yes, definitely yes). The Table 10 shows overall results:

In order to In terms of characterising the current state developing information technology competencies, respondents put the greatest emphasis on the development of the pupils' ability to search for and obtain information from electronic information sources. Among other abilities, which are from the viewpoint of the current state developed more than partially, belong the ability to Respects of the code of conduct in digital environment, Process and integrate information, Present information and store it for the given purpose and recipients.

Certainly it is displeasing that likewise in the VIV06 research, the ability to Generate new information through interpreting or use current information, Think critically, make a decision, Know how to use problem-solving strategies and information orientated tasks, Understand technological principles and processes, Think algorithmically, formulate instructions, received the lowest evaluation mark from the standpoint of the current situation.

\section{d) Structure of teachers' ICT competencies}

In the area of teachers' ICT competencies, the primary aim was to map their level from multiple viewpoints, chiefly to establish the level of respondents' ICT competencies and simultaneously ascertain their evaluation of the competencies of other teachers at school. The secondary focus was the minimum acceptable level of ICT competencies of teachers of ICT-orientated subjects. The primary aim was explored through the self-evaluation responses and evaluations of the fellow-teachers' competencies. Regarding the secondary aim, respondents expressed their 
opinion on the minimum level of ICT competencies, which should be acquired by all teachers of ICT-orientated subjects (Štípek, Rambousek, Prochazka, 2013).

Given the size of the sample, the level of respondents' competency development in the said area was not thus researched through methods seeking to verify this level directly. The research did not aim to test teachers' knowledge and skills but it sought to employ self-evaluation and evaluation declarations of respondents, in other words methods, which are considered valid and reliable. Other research findings showed that a stated and verified level of literacy only differ in the nominal value of 3\%. The Eurostat study on e-Skills issues confirm that self-evaluation approach is a good approximation of their real competencies and that respondents do not try to overestimate their knowledge and skills.

Respondents were presented with a six-level scale expressing the levels of teachers' ICT competency development by means of various ways of using technologies in instruction with apparent gradation:

Level 1: A teacher does not have a sufficient command of ICT, uses or employs ICT skills neither in the classroom nor in lesson planning.

Level 2: A teacher occasionally uses presentations, learning programmes, applications or games with a technical assistance support.

Level 3: A teacher can use standard functions of office software and the Internet (e-mail, www browser). They scarcely employ these competencies in the classroom.
Level 4: A teacher is able to use a wider range of software and online services. They are able e.g. to make presentations, tables and simple web pages. They also integrate these activities in their teaching.

Level 5: A teacher is capable of creative use of ICT to support their teaching, they are able to find, modify and produce learning materials and applications and adjust them to pupils' needs.

Level 6: A teacher is able to use, administer and develop ICT. They are able to adapt themselves to new technologies. They encourage pupils to use advanced programmes and applications and create their own materials.

Respondents were invited to rate on the scale their answers to the three following questions:

INF_ACT On average how would you rate on the scale teachers of ICT-orientated subjects in your school?

INF_MIN What is a minimum level a teacher of ICTorientated subject should have?

RESP_ACT How would you rate yourself in terms of technology skills on the scale now?

The summary frequency table for all questions shows a basic situation of the distribution of respondents' choices and comparison with the VIV06 results. VIV06 survey comprised 930 respondents, VIV12 survey 1,183 respondents. The frequency data are presented relatively in the table for the sake of clarity and comparability (refer to Table 11). 


\begin{tabular}{|c|c|c|c|c|c|c|c|}
\cline { 3 - 8 } \multicolumn{1}{c|}{} & \multirow{2}{*}{ question } & \multicolumn{7}{|c|}{ selected degree } \\
\cline { 3 - 8 } & & 1 & 2 & 3 & 4 & 5 & 6 \\
\hline \multirow{4}{*}{ VIV06 } & INF_ACT & $1 \%$ & $2 \%$ & $10 \%$ & $28 \%$ & $40 \%$ & $19 \%$ \\
\cline { 2 - 8 } & INF_MIN & $1 \%$ & $0 \%$ & $5 \%$ & $25 \%$ & $42 \%$ & $26 \%$ \\
\cline { 2 - 8 } & RESP_ACT & $0 \%$ & $0 \%$ & $9 \%$ & $24 \%$ & $48 \%$ & $20 \%$ \\
\hline \multirow{4}{*}{ VIV12 } & INF_ACT & $0 \%$ & $1 \%$ & $5 \%$ & $14 \%$ & $51 \%$ & $29 \%$ \\
\cline { 2 - 8 } & INF_MIN & $1 \%$ & $1 \%$ & $2 \%$ & $23 \%$ & $45 \%$ & $28 \%$ \\
\cline { 2 - 8 } & RESP_ACT & $0 \%$ & $0 \%$ & $2 \%$ & $13 \%$ & $53 \%$ & $32 \%$ \\
\hline
\end{tabular}

Table 11: Relative frequency of the distribution of respondents' choices (VIV06 - VIV12)

The first question (INF_ACT) inquired what level of ICT competency development can be on average assigned to teachers of informatics subjects in respondent's school. Both the median and mode of choices in VIV06 and VIV12 are equivalent to level 5 on the scale. However, the last 6 years have seen an increase in choices of level 5 from $40 \%$ to $51 \%$. The highest offered level (6), which can also by marked as a production level to a certain extent, has also experienced a growth, from $19 \%$ to $30 \%$. Differences are statistically significant at $\mathrm{p}<0.01$.

On the other hand, the distribution of choices presented in frequency tables also shows substantial employment of lower scale levels ( 3 and $4 ; 5 \%$ and $14 \%$ ), which cannot be considered sufficient for teachers of ICT-orientated subjects, though. Overall comparison of VIV12 and VIV06 and evident positive shift to higher levels of ICT competencies of teachers of informatics subjects are clearly specified in the chart (refer to Figure 2).

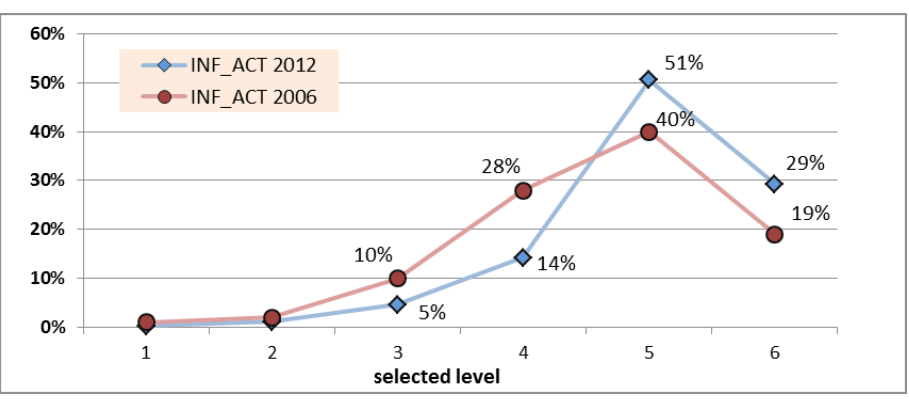

Figure 2: Comparing Teachers' ICT Competencies of VIV12 and VIV06

The second question examined the minimum level of ICT competency that a teacher of ICT-orientated subjects should acquire generally (INF_MIN). Also here, both the median and mode approach level 5 on the scale and in comparison with VI V06 the overall distribution of respondents' choices does not show any statistically significant difference.

The VIV12 analysis also brought interesting findings based on respondents' answers to the question on minimum required level (INF_MIN) in relation to evaluation of the current situation in their school (INF_ACT). Respondents rating a current level of competencies of their colleagues lower scale levels ( 3 and 4) also generally stated lower requirements on minimum level of teachers of informatics subjects. For illustrative purposes, the following chart on the question of minimum level shows the comparison of the distribution of choices of the sub-group of respondents rating the current state a 3 and a sub-group rating it a 6. The figure differences at level 5 and 6 are statistically significant with error probability of $\mathrm{p}<0.01$ (refer to Figure 3). 
The chart clearly shows a difference in requirements on minimum level as stated above. This phenomenon can be explained by the relativisation on the scale to a certain degree. Yet, the research team attributes these causes i.a. to the relativisation of requirements (not the scale), i.e. minimum requirements are partially seen as an aim, which is to be achieved over an uncertain time horizon. Therefore respondents' responses as to minimum requirements reflect current situation of their schools.

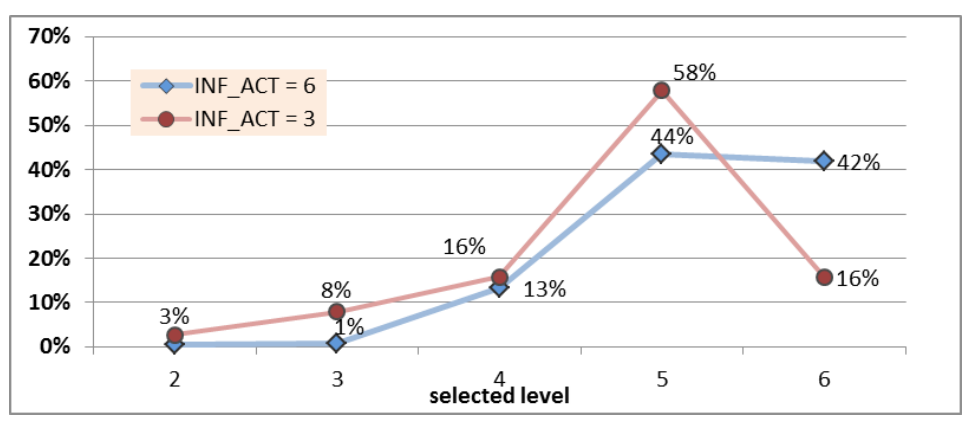

Figure 3: Comparing INF_MIN choices of INF_ACT (VIV12) sub-groups

The third question explored the level of technology competencies of the respondents themselves (RESP_ACT). Majority of respondents (53\%) rate their current technology competencies a 5 and one third of the respondents (32\%) rate themselves the highest level. $15 \%$ of the respondents scored a 3 and 4, thus not reaching even the minimum required level of competencies (INF_MIN median). A detailed analysis of this issue (the relation of RESP_ACT and INF_MIN) reveals some more interesting facts plotted in the graph presenting similar VIV06 data as well for the sake of comparison (refer to Figure 4).

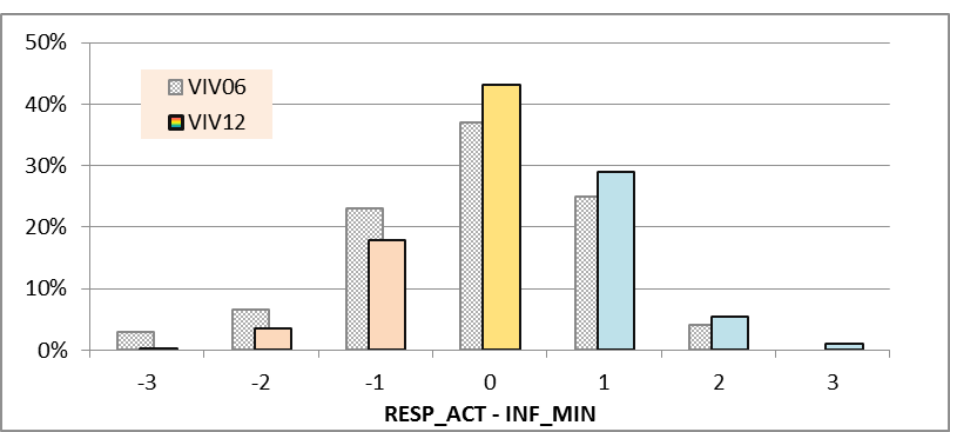

Figure 4: Distribution of the RESP_ACT - INF_MIN values

The graph (Figure 4) shows distributions, or numbers of respondents according to the established difference (as measured by the scale levels) between the current level of respondents' ICT competencies (self-evaluation) and a minimum required level for informatics teachers they declare (RESP_ACT - INF_MIN difference). $35 \%$ of respondents (last three columns) rate themselves higher level than the minimum level they require, $43 \%$ (the middle column) declare the same levels. $22 \%$ of respondents rate themselves lower level than what they consider the minimum acceptable level. From this it follows that almost one quarter of all respondents do not consider their own ICT competencies acceptable, or sufficient for teaching ICT-orientated subjects in primary and lowersecondary school. However, in comparison with the outcomes of the same VIV06 analysis, we may conclude that the ratio of the respondents rating their competencies (RESP_ACT) lower than what they defined as a minimum level (INF_MIN) has significantly decreased from $33 \%$ to $22 \%$.

Sub-groups of respondents defined by the difference between the evaluation of their own and required level (RESP_ACT 
- INF_MIN), i.e. based on a relative indicator, differ in the choice of the concrete level (absolute indicator). Respondents rating themselves a lower level than the one they consider as a minimum, have higher requirements on this minimum and vice versa.

Besides the self-evaluation, a question on teachers' preferences on teaching various thematic units was introduced to complete the information on respondents' competencies. It was presumed that respondent's attitude to teaching a certain thematic unit is significantly influenced by the respondent's notion of their competencies in this unit. Other motives can effects the attitude to teaching as well, however taking into account the structure of choices the results can have the anticipated informative value. In order to increase the informative value of the question, it was integrated into the questionnaire application so that its main purpose would not be obvious and that it would not tempt the respondent into providing a better answer and that it would allow to give an indirect account of respondent's competencies. The question on attitudes to and preferences on various thematic units was meant to help to identify not just the level but also the structure of respondent's ICT competencies.

In the said question, the respondents were presented with 14 ITC thematic areas. Their task was then to show their attitudes to the areas in terms of their willingness, or preference to stand in (teach) on the following scale: 1 - I want to stand in, 2 - If necessary, I can stand in, 3 - No, I don't want to stand in. In order to evaluate respondents' level of ICT competencies, their choices were categorized on a dichotomy scale a) positive (including answers 1 and 2), and b) negative (including answer 3), as Figure 5 shows.

The Figure 5 shows proportions of the representation of choices in particular categories („I want", „I can“, „I don't want") not including the number of respondents, who did not evaluate the thematic unit at all. Complete relative frequencies are presented in the table.

Statistical analysis additional allowed for identification of thematic fields with a strong relation to the stated level of respondents' ICT competencies. The following six areas showed the most intensive relations: PC hardware and software, Algorithms and the basics of programming, Computer graphics, Audio and video on the computer, Creating and publishing websites and Fundamentals of database systems, database use and design.

The higher the level of respondent's own ICT competencies (self-evaluation), the keener on the thematic units they were, or they were willing to stand in, and vice versa. The lower the selfevaluation, the smaller the number of preferred thematic units. The other eight thematic areas did not support these findings. Thus we can briefly conclude with the following interpretation of the analysis: the differences in the level of respondents' ICT skills are primarily defined by the differences of their competencies in the given six thematic fields.

The overall level of teachers' ICT competencies is also reflected in their approaches and attitudes towards further development of their own competencies and ways of education, in terms of both the subjective evaluation of its various forms and the preference of various strategies. For example, teachers generally welcome ICT-orientated courses, which are ensured for them, nevertheless the evaluation of their importance decreases along with the increasing level of their ICT competencies. Respondents rating their skills the top level on the ICT competencies scale, find the IT courses almost useless for their future development. 


\begin{tabular}{|c|c|}
\hline & $\begin{array}{lcr}1 & 2 & 3 \\
\text { not selected }\end{array}$ \\
\hline & $\begin{array}{c}79 \% 8 \% 0 \% \\
13 \%\end{array}$ \\
\hline $\begin{array}{l}\text { Searching for and retrieving } \\
\text { information from the internet }\end{array}$ & $\begin{array}{c}73 \% 16 \% 0 \% \\
10 \%\end{array}$ \\
\hline & $\begin{array}{c}69 \% 19 \% 1 \% \\
11 \%\end{array}$ \\
\hline $\begin{array}{l}\text { Working with spreads } \\
\text { processing data, creati }\end{array}$ & $\begin{array}{c}59 \% 25 \% 4 \% \\
11 \%\end{array}$ \\
\hline s & $\begin{array}{c}52 \% 27 \% 1 \% \\
20 \%\end{array}$ \\
\hline $\begin{array}{l}\text { Basic user skills, working in an } \\
\text { operating system, file management }\end{array}$ & $\begin{array}{c}45 \% 34 \% 9 \% \\
13 \%\end{array}$ \\
\hline Comp & $\begin{array}{c}44 \% 31 \% 11 \% \\
13 \%\end{array}$ \\
\hline $\begin{array}{l}\text { the structure and } \\
\text { uters }\end{array}$ & $\begin{array}{c}41 \% 40 \% 7 \% \\
12 \%\end{array}$ \\
\hline cooperation in & $\begin{array}{c}36 \% 42 \% 9 \% \\
13 \% \\
\end{array}$ \\
\hline $\begin{array}{l}\text { n the computer - } \\
\text { g multimedia }\end{array}$ & $\begin{array}{c}28 \% 36 \% 23 \% \\
13 \%\end{array}$ \\
\hline $\begin{array}{l}\text { Basics of information theo } \\
\text { types, size, sources, storin }\end{array}$ & $\begin{array}{c}19 \% 42 \% 25 \% \\
14 \%\end{array}$ \\
\hline $\begin{array}{l}\text { Creating and publishing websites } \\
\text { (HTML, CSS, PHP etc.) }\end{array}$ & $\begin{array}{c}17 \% 31 \% 40 \% \\
12 \%\end{array}$ \\
\hline $\begin{array}{l}\text { Using databases - fundamentals of } \\
\text { database systems, database design }\end{array}$ & $\begin{array}{c}4 \% 22 \% 55 \% \\
19 \%\end{array}$ \\
\hline $\begin{array}{l}\text { Algorithm design and programming } \\
\text { - developing algorithmic thinking }\end{array}$ & $\begin{array}{c}\% 11 \% 28 \% \\
57 \%\end{array}$ \\
\hline
\end{tabular}

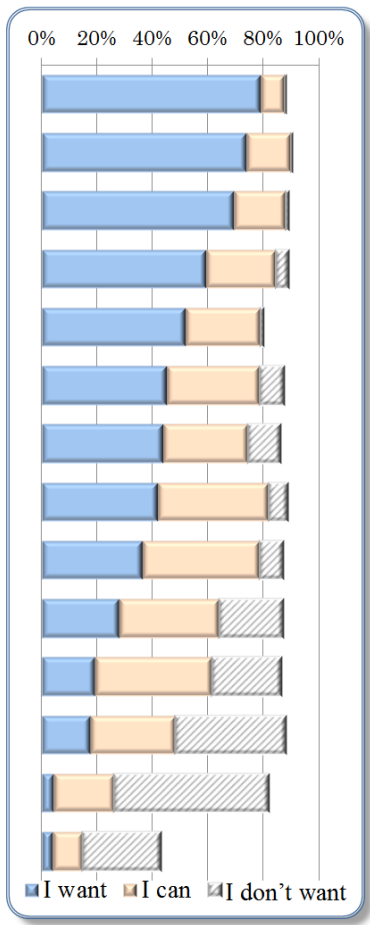

Figure 5: Distribution of respondents' choices in terms of the willingness to stand in for another teacher and teach the thematic units - ranked according to the occurrence of the answer ( 1 = I want to stand in for another teacher)

The level of teachers' competencies can further be reflected in lesson planning, i.e. in the choice of the sources. The significance of various types of information and methodology sources for the support of learning and teaching process and designing materials or worksheets for pupils was explored in another part of the questionnaire. Respondents were to comment on the significance of, or extent to which they use the given source by a 5-level scale. The findings were categorized by the level of respondents' ICT competencies and a follow-up comparison of the significance of sources was carried out. The most striking links between the level of respondent's competencies and the significance of lesson planning sources were identified in professional computer literature, course books, thematically oriented web portals, using electronic portfolio, or teacher's own production (Fuglík and. Černochová, 2012).

\section{e) Implementation of ICT competencies into educational activities}

From a viewpoint of implementing ICT into school life and the educational environment, the following ways for using technologies prevail: handing in papers and tasks in electronic form by pupils in various subjects, preparing supplementary teaching materials, and using technologies outside school. ICT tools to organize, monitor and assess the learning process are rarely used and virtual learning environment are seldom used as well (refer to Table 12). 


\begin{tabular}{|l|c|c|}
\cline { 2 - 3 } \multicolumn{1}{l|}{} & M & A \\
\hline Pupils use ICT in various subjects, not only ICT subjects & 5 & 4,3 \\
\hline $\begin{array}{l}\text { Teachers use ICT to prepare lessons and create their } \\
\text { own teaching materials }\end{array}$ & 4 & 4,3 \\
\hline $\begin{array}{l}\text { Teachers use ICT to directly support their teaching in } \\
\text { various subjects }\end{array}$ & 4 & 4,2 \\
\hline $\begin{array}{l}\text { ICT are available at school and pupils can use ICT also } \\
\text { after school }\end{array}$ & 4 & 3,7 \\
\hline Pupils create and submit their work electronically & 3 & 3,4 \\
\hline $\begin{array}{l}\text { Teachers use ICT to plan, organise, check and evaluate } \\
\text { the learning process }\end{array}$ & 3 & 3,2 \\
\hline Pupils create and submit their work electronically & 3 & 3,1 \\
\hline $\begin{array}{l}\text { Teachers use ICT to communicate with pupils and } \\
\text { parents and to send materials }\end{array}$ & 3 & 3,1 \\
\hline Pupils communicate with their teacher electronically & 3 & 3,0 \\
\hline $\begin{array}{l}\text { School provides pupils with the internet connection on } \\
\text { the school WLAN }\end{array}$ & 3 & 2,9 \\
\hline Teachers use ICT mostly for administrative work & 3 & 2,6 \\
\hline $\begin{array}{l}\text { Teachers together with their pupils realise on-line } \\
\text { learning projects using ICT }\end{array}$ & 2 & 2,1 \\
\hline $\begin{array}{l}\text { Teacher, pupils and parents have on-line access to study } \\
\text { results }\end{array}$ & 1 & 1,9 \\
\hline $\begin{array}{l}\text { Teachers use a virtual educational environment to } \\
\text { support the learning process }\end{array}$ & 1 & 1,6 \\
\hline
\end{tabular}

Table 12: Degree of agreement of the statements - ranked from the highest resulting agreement of the statement - in the case of equal medians, the order is determined by mean

The extent and level of implementing ICT and information technology competencies into school life and educational environment develop mainly in the field so this does not place significant time and professional requirements on the teacher. The determining factor of the level of ICT implementation into school life and environment is not the significance of the implementation for pupils' development of information technology competencies, but the time burden, which this way would place on the teacher. Teachers with a higher level of information technology skills require their pupils use ICT as a common tool for work and communication.

\section{Discussion}

In terms of representativeness of the results of research VIV12 be noted that, the sample consisted of 1,183 teachers of ICTorientated subjects returning the questionnaires fully or partially completed. Both sexes were equally represented in the sample, it comprised $46 \%$ of men and $54 \%$ of women. Compared to the VIV06 research, we may notice a slight shift in favour of women (51\% men, 49\% women). This distribution corresponds with the characteristic of teachers of ICT-orientated subjects even though the total of 57,815 primary and lower secondary school teachers comprised only 16\% men and 84\% women in 2012 .

There was also a fairly even geographical distribution of the respondents and it corresponded quite accurately with the overall distribution of primary and lower-secondary schools in the Czech Republic, both in terms of the number of schools representing a particular region from the viewpoint of the size of the location where the respondents' schools were located, and in terms of the size of the respondents' schools represented by the number of pupils. Although 3,500 schools were randomly selected out of the total of 4,040 primary and lower-secondary schools, the extent of the sample was considerable and in many parameters the sample corresponded with the overall 
distribution of the indicators, it was not possible to ensure full representativeness of the sample corresponding with the random sampling.

The results above can be, therefore, related to the given sampler of respondents, the generalization and judgments should be made very carefully.

Similarly oriented and extensive research was carried out within the project VIV06. The findings of the project VIV12 have been compares with findings of the research VIV06 in the relevant sections above. A considerable part of findings VIV12 are similar to the findings VIV 06, but in generally we may nevertheless observe a positive trends.

\section{Conclusion}

Overall, based on the findings of the first stage of the VIV12 research project in connection to observed curricular, processional and organizational aspects of ICT literacy education in primary and lower-secondary schools in the Czech Republic bearing in mind the above mentioned limited representativeness of the sample respondents, we can say:

ICT literacy education does not concern only the ICT-orientated subjects in primary and lower-secondary schools. Using ICT in the subjects that do not focus on informatics primarily and in a number of educational ICT activities which are not directly linked to subject contributes significantly to the development of information technology competencies.

ICT literacy education realized in ICT-orientated subjects tends to focus only on user skills and mastering basic applications and tools. Informatics and algorithmically formalistic topics and problem-solving skills, supporting creativity and creative thinking in pupils and building up modern broadly understood ICT technology literacy are not considered important or are postponed to secondary school.

The structure and level of information technology skills of informatics teachers fundamentally influence the conception and orientation of ICT literacy education in these subjects. Teachers consider the thematic units or skills which they cannot master themselves and consider them demanding of a lower importance for the development of information technology literacy in primary and lower-secondary schools and do not commit themselves to them.

ICT competencies of teachers of ICT-orientated subjects range from basic, or pre-intermediate user skills to the level of professional IT experts. One sixth of the respondents rate their competencies a level which cannot be considered sufficient for adequate ICT literacy education and the majority of them are aware of their shortcomings. Some respondents imply that they do not consider their ICT skills as sufficient for teaching ICTorientated subjects in primary and lower-secondary schools.

From this it follows that the realization of IT education in the Czech Republic is, compared to other fields of primary education, problematic to say the least. The structure and level of IT teachers' ITC competencies fundamentally affects the concept and orientation of IT education realized in these subjects. The structure and level of teachers' ICT competencies do not only affect lesson planning and obviously teaching, but it also to a great extent determines teachers' attitudes and ambitions in terms of their further development. Based on the comparison with the VIV06 results we may nevertheless observe a positive trend in a gradual shift of IT teachers' ICT competencies towards higher levels. 
One of the conditions of the effective development of pupils' information technology competencies is, apart from content orientation of ICT literacy education, also an extended implementation of ICT and its skills into various school subjects and school life. The pupils' information technology competencies are mainly developed in the environment, where teachers of different subjects use technologies to prepare their teaching and learning materials, to organize, monitor and assess the learning process; they use them also for communication with the pupils and for internet learning projects.

\section{Acknowledgements}

This work was supported by grants of the Czech Science Foundation P407-12-1541 Information Technology Competencies of Children and their Development in Primary and Lower Secondary Schools

\section{References}

Ala-Mutka, K. (2011). 'Mapping Digital Competence: Towards a Conceptual Understanding'. European Union, 2011.

Ala-Mutka, K. et al (2008). 'Digital Competence for Lifelong Learning'. Institute for Prospective Technological Studies, Joint Research Centre, European Commission.

Anderson, R. (2008) 'Implications of the information and knowledge society for education'. In J. Voogt \& G. Knezek (Eds.), 'International handbook of information technology in primary and secondary education. New York: Springer.

European Commission. (2006). 'Information Society and Education: Linking European Policies'. Luxembourg: Office for Official Publications of the European Communities.
European Commission. (2010). 'A Digital Agenda for Europe, COM(2010)245 final'.

European Parliament and the Council. (2006). 'Recommendation of the European Parliament and of the Council of 18 December 2006 on key competences for lifelong learning'. Official Journal of the European Union, L394/310.

Eurydice. (2002). 'Key Competencies. A developing concept in general compulsory education'. Brussels: Eurydice.

Fuglík, V. and Černochová, M. (2012). 'Research Findings on Implementing Student Portfolios into Teacher Education'. In: In 9th International Conference on Efficiency and Responsibility in Education (ERIE 2012), Praha: Czech University of Life Sciences Prague, pp. 130-139.

ITU. (2012). 'The World Summit on the Information Society'. WSIS Forum 2012: Outcome Document. International Telecommunication Union: Geneva. [Online], Available: http://groups.itu.int/LinkClick.aspx?fileticket=-yre0EkP84E \%3d\&tabid=2103. [2013-27-7].

Rambousek, V. et al (2007). 'Výzkum informační výchovy na základních školách'. Plzeň: Koniáš.

Štípek, J. et al (2008). 'Implementation of ICT competencies into educational activities'. In Pesrpective in Education Process at Universities hit Technical Orientacion in Visegrad Countries. Nitra: UKF\&UNESCO, pp. 234-240.

Štípek, J., Rambousek, V., Procházka, J. (2013). 'ICT literacy education and teachers' ICT competencies'. In Efficiency and Responsibility in Education 2013. Praha: Czech University of Life Sciences Prague, pp. 587-594. 